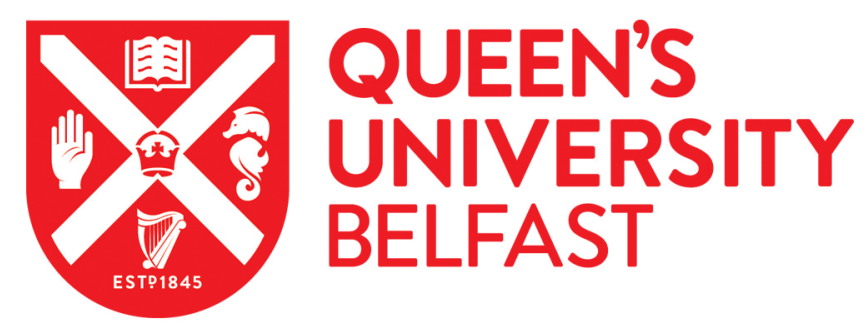

\title{
Commissions and Local Government Reform: Expressed Leadership Identities of Commissioners in Inquiries Proposing Municipal Mergers in Northern Ireland and New South Wales
}

Wallis, J., Brodtkorb , T., Dollery, B., \& MacCarthaigh, M. (2017). Commissions and Local Government Reform: Expressed Leadership Identities of Commissioners in Inquiries Proposing Municipal Mergers in Northern Ireland and New South Wales. Politics \& Policy, 45(2), 285-308. https://doi.org/10.1111/polp.12199

Published in:

Politics \& Policy

Document Version:

Peer reviewed version

Queen's University Belfast - Research Portal:

Link to publication record in Queen's University Belfast Research Portal

Publisher rights

(c) 2017 Policy Studies Organization.

This work is made available online in accordance with the publisher's policies. Please refer to any applicable terms of use of the publisher.

\section{General rights}

Copyright for the publications made accessible via the Queen's University Belfast Research Portal is retained by the author(s) and / or other copyright owners and it is a condition of accessing these publications that users recognise and abide by the legal requirements associated with these rights.

Take down policy

The Research Portal is Queen's institutional repository that provides access to Queen's research output. Every effort has been made to ensure that content in the Research Portal does not infringe any person's rights, or applicable UK laws. If you discover content in the

Research Portal that you believe breaches copyright or violates any law, please contact openaccess@qub.ac.uk. 


\title{
Commissions and Local Government Reform: Expressed Leadership Identities of Commissioners in Inquiries Proposing Municipal Mergers in Northern Ireland and
} New South Wales

\begin{abstract}
Commissions of inquiry are frequently used as venue-alteration mechanisms to investigate and 'depoliticise' local government reforms. Through the application of a leadership identity framework that examines the judgements that commission chairs make during the course of the inquiry, this paper explores the roles that commission chairs play as interpretive authorities. The judgments that commission chairs make about the scope of stakeholder engagement and whether to adjust the agenda of the inquiry generate four types of leadership identity: conservator, consolidator, advocate and catalyst. The leadership identity framework is applied to two commissions conducting inquiries into proposed structural reform of local government in two sub-national systems: Northern Ireland and New South Wales. The application of the framework reveals that the commission process itself leads to a shift from a conservator to a consolidator leadership identity in both systems, despite their different and distinctive historical, social and political contexts.
\end{abstract}

Keywords: Local government reform, Municipal mergers, Commissioners, Leadership,

\section{Introduction}

For the past few decades, across the developed world, national or regional governments have made persistent efforts, of varying degrees of intensity, to reform local government systems (see, for example, Denters and Rose, 2005; Shah, 2006; Dollery, Garcea and LeSage, 2008; Dollery and Robotti, 2008). In Municipal Reform in Canada, Garcea and LeSage (2005) developed a useful analytical taxonomy comprising five discrete types of local government reform: structural reform, jurisdictional reform, functional reform, financial reform, and ‘internal governance and management reform’. In contemporary local government, reform programs have sought to address diverse aspects of local government systems across all of these categories. 
Numerous policy instruments have also been employed (see, for instance, Dollery, Grant and Kortt, 2012, for a recent survey of the literature) to achieve desired types of reform. These instruments include fiscal equalisation measures, like the intergovernmental grants system in Sweden (Johansson 2003), performance monitoring, such as the Comprehensive Performance Assessment (CPA) in Britain (Game 2006), asset management and reporting (Dollery, Kortt and Grant, 2013), co-production of local services (Andrews and Brewer, 2013), shared service provision (Tomkinson, 2007), and compulsory council consolidation (Lago-Penas and Martinez-Vazquez, 2013).

Despite the existence of different types of local government reform, and the variety of policy instruments available to pursue them, reducing the number of local councils through amalgamation is sometimes perceived as a panacea for local government problems by national or regional governments. Advocates of compulsory council consolidation have long claimed - using a variety of justifications - that numerous advantages derive from the structural transformation of many small local authorities into fewer, larger, local government entities (Sancton, 2011). Proponents of mandatory municipal mergers used to emphasise cost reductions and other scale efficiency dividends purportedly flowing from council consolidation. However, the documented failure of amalgamated entities to achieve the claimed savings targets has resulted in more recent municipal mergers being premised on their ability to increase the administrative and technical capacity of local authorities (Dollery, Grant and Kortt, 2012). Furthermore, some contemporary campaigns aimed at forced amalgamation, such as efforts to consolidate all five councils in the Hawke's Bay Region of New Zealand, have invoked the ostensible ability of regional leadership based on large merged local authorities to drive faster regional growth and development (McGredy Winder \& Co, 2013a, 2013b). Forced amalgamation is thus an example of a 'pet solution' which, according to Kingdon (1995), proponents commit to and then lie in wait for an opportunity to 
apply to different problems, depending on their assessment of the receptivity of the relevant policy community to the proposal.

Opponents of compulsory council consolidation have stressed the divisive nature of amalgamations, the lack of empirical evidence supporting their purported benefits, the equivocal outcomes observed in past mergers, and the resulting diminution of local democracy (Faulk and Hicks, 2011). In general, the academic literature has been sceptical of the outcomes of mergers, and the weight of empirical work has fostered doubt about the efficacy of amalgamation as a way to address problems in local government systems (see, for example, Lago-Penas and Martinez-Vazquez, 2013). As Brunnson and Olsen (1993) have demonstrated, all organisation reforms lead to new interdependencies, and organisational mergers inevitably produce new challenges and unintended consequences, ranging from escalating implementation costs to trade union opposition.

Given its controversial nature, it is hardly surprising that most national and sub-national governments face resistance when attempting structural reform through compulsory council consolidation. In an effort to 'depoliticise’ structural reform programs of this kind, governments of all political persuasions frequently deploy commissions of inquiry to investigate local government reform, using the commissions as venue-alteration mechanisms, 'replacing one volatile critical audience (the media, the opposition and the public) with a much slower-moving and predictable audience - the inquiry commission' (Sulitzeanu-Kenan, 2008, 10; see also Pralle, 2006 and Princen, 2010).

Demand-side considerations, such as why governments choose to appoint these bodies, and what role they play in the policy process, dominate the substantial literature on commissions of inquiry (see, for example, Chapman 1973; Clokie and Robinson 1937; D’Ombrain 1997; Dollery et al 2008; Gilligan 2002; Mackintosh 1970; Prasser 1985, 1994, 2006; 
Resodihardjo 2006; Roberts 1977; Robshaw 1961; Sheriff 1983; Sulitzeanu-Keenan 2006;

Weller 1994; Zegart 2004). Comparatively little attention, however, has been paid to supplyside issues, such as the leadership behaviour and motivation of commission chairs. A notable exception is Rowe and McAllister (2006: 110-111), who report the results of interviews with these actors, finding that they see themselves as 'having a distinctive and constructive role in the policy process', with many saying they would not have accepted appointment had they considered their role to be 'merely cosmetic'. This paper seeks to develop this supply-side focus through a comparative study of the role of commissions in the structural reform of local government in two different systems: Northern Ireland and NSW. These two instances of inquiries considering local government reform provide instructive material for a comparative study of structural reform through forced mergers. In the case of NSW, the process initiated with the inquiries led directly to the decision to implement the mergers, while in the case of Northern Ireland, the process went through multiple stages, seemed to involve more deliberation, and resulted in other instruments of local government reform eventually being employed alongside mergers.

The paper is divided into five parts. Section 2 provides an account of the theoretical framework used in the analysis of the leadership identity of the members of commissions of inquiry. Section 3 outlines the local government reform process in Northern Ireland, and section 4 outlines the Independent Local Government Review in New South Wales, together with subsequent developments. Section 5 compares the role of the commissions of inquiry in the two reform processes, and evaluates the light shed on them by an analysis of the leadership identities of the members of the commissions.

\section{Theoretical framework}


The public service bargain framework, developed by Schaffer (1973), Hood (2000) and Hood and Lodge (2006), has primarily been applied to characterize the key features of the explicit and implicit relationships between senior civil servants and their political masters. We propose to extend the scope of application of this framework to encompass the relationships between commissioners and those they serve. The most general formulation of the public service bargain framework can be found in Hood and Lodge (2006), who distinguished two categories: the agency bargain, where public servants serve political masters; and the trustee bargain, where they serve an autonomous entity, such as the state. Four sub-types can be discerned within each category. For instance, agency bargains can be delegated in either a complex (multiple principal) or simple (single principal) form or directed in either a serial or personal loyalist form. Similarly, trustee bargains can be 'representational' in a consociational or selective form, or 'tutelary' with trustees being set apart as moralistic exemplars or 'experts on top'.

It is illuminating to apply this framework to compare the traditional Westminster-type 'Schafferian' bargain between political leaders and senior civil servants with the bargain between political leaders and the individuals they appoint to serve on commissions of inquiry. The former bargain has traditionally been a serial loyalist, directed agency-type bargain. Senior civil servants are expected to be loyal, discrete and anonymous partners of successive governments, and in turn, expect steady increases in status and responsibility. By contrast, commissioners have conventionally related to political leaders through short-term trustee bargains of the tutelary type. They are expected to be loyal and responsible to an autonomous entity that operates in a realm outside of politics. Indeed, some of the most interesting work on commissions has come from scholars applying a social constructionist perspective. Such an approach elucidates the way in which commissioners act as 'interpretative authorities' 
constructing an interpretation of both the state they serve and the 'public interest' they seek to advance to a potentially critical audience of current and future political leaders (see Sherif 1983; Ashforth 1990; and Brown 2000).

We contend that the more open-ended nature of commission bargains has two implications. Firstly, unlike the traditional 'Schafferian' bargain, which has come under pressure from New Public Management-type reforms that emphasise an individualist direction (Savoie 2003; Moran 2003; Foster 2005; Page 2007; Dollery, Wallis and McLoughlin 2007), the conventions governing commission bargains have remained relatively stable. Classic discussions of these conventions, such as Clokie and Robinson (1937), thus maintain their relevance in a way that classic works on the politician-administrator relationship, like Goodnow (1922) and Weber (1922), have not.

Secondly, in exercising their judgements as interpretative authorities, commissioners effectively layer a leadership identity onto this primary role. Thus, from a praxis perspective on leadership (Korac-Kakabadse and Korac-Kakabadse 1997; Heifetz and Linsky 2002), commissioner judgments are based on their interpretation of what they should or should not recommend, bounded by the discretion inherent in their roles. Through these judgments, they are proposing that a layer of leadership identity be added to their primary, judge-like, responsibility, thereby giving their audiences the opportunity to legitimate, contest or reject their proposals. This identity contributes to a leadership legacy for the commissioners which is socially constructed from references to the commission's report in policy discussions by the appointing government, by future governments, and other social actors, including future commissions. 
There are two foundational types of judgment that need to be made over the course of the inquiry. The first concerns the extent of stakeholder engagement. This would involve commissioners balancing (i) the greater legitimacy (Resohardijo 2006), the increased scope to develop their own view independent of an insider community of government officials and well-connected interest groups (Howard 1987), as well as the enhanced capacity to generate fresh ideas and perspectives from a widening circle of 'outsiders' consulted in the course of the inquiry, against (ii) the possibility of prolonging the inquiry and rendering it something of a 'garbage can' (Cohen et al 1972) in which diverse policy entrepreneurs simply ‘dump’ their 'pet problems' and solutions (Kingdon 1995), so that it loses focus and fails to draw a coherent set of conclusions. In exercising judgment on this matter, commission chairs must strike a balance between actively seeking greater public participation and maintaining a clear focus and direction.

The second type of judgement commissioners must make relates to how far they adjust the commission's agenda beyond that intended by the appointing politicians. Do they (i) voluntarily limit their 'labors to those proposals that are likely to succeed' (Ashforth 1990) by proposing little more than an incremental change to the agenda of the appointing authorities, or do they (ii) recommend what Hall (1993) has termed a third order change in the policy agenda through: (a) floating innovative policy options and/or; (b) reframing policy priorities? The latter options face the risk of political rejection, although commissioners may judge it necessary to 'break the ice’ by making proposals that may not have been considered previously, in order to render such proposals 'discussable'. These judgments will have to be finalized when commissions submit their report; however, the commission may decide at the planning phase whether it will keep its focus within the narrow limits prescribed by its terms of reference, or show a willingness to go beyond these limits and seek to identify root causes 
of problems (Resohardijo 2006), or discover and amplify best practices in the area of inquiry (Wallis 2013).

The more the commission's recommendations diverge from the policy changes intended (whether explicitly or implicitly) by the appointing authority, the greater is the risk that these office-holders will ignore them. Considerable credit may accrue to a chair who succeeds in persuading an incumbent government to implement unanticipated policy changes, although refusal by the government to implement those changes cannot necessarily be interpreted as an indication of poor judgment by the commission (e.g., Sheriff 1983). Thus, even if its recommendations are rejected, commission reports can nevertheless provide ammunition for advocacy coalitions (Sabatier 1988) seeking policy change. Moreover, the reports can assume an archival significance if they become landmarks of contemporary wisdom about a policy problem, or even points of reference for future discussion.

The balancing of risk and reward implicit in judgments about stakeholder engagement and agenda adjustment can give expression to a leadership identity that can be layered on to the interpretative authority identity that commissioners are conventionally expected to assume. There are a variety of such identities and Table 1 proposes a typology of four possible leadership identities.

\section{$<$ TABLE 1 ABOUT HERE $>$}

First, there is a conservator identity that is implicated in decisions to take a low-risk approach to both stakeholder engagement and agenda adjustment. Brown (2000) described how the leadership aspiration of such a chair would be to 'ameliorate anxieties' by offering 
'acceptable interpretations' that bolster the legitimacy of the solutions preferred by the appointing office-holders, as opposed to promoting unexpected or innovative solutions in response to the events or situations that prompted the inquiry.

Second, there is the consolidator leadership identity (Haggard and Kaufman 1992), which can be layered upon commissioner identities when commission chairs 'justify government decisions' (Prasser 1994) by forging a consensus among the interests represented on the commission (Zegart 2004) and building support among the societal actors they consult (D’Ombrain 1997). Thus, a consolidator chair would make the judgments that the commission should take a low-risk approach to agenda-adjustment, but a higher-risk approach to stakeholder engagement.

Third, an advocate leadership identity can be constructed through decisions to take the highrisk approach of advocating an innovative or unexpected policy proposal while, at the same time, limiting the scope of engagement to insiders so as to reduce the opportunity for outsider groups to mobilize opposition to emerging recommendations before the report is published.

Fourth, a catalytic leadership identity will be expressed by chairs who recommend more farreaching and risky agenda adjustments that emerge from extensive stakeholder engagement that gives rise to an 'open-minded' process of sense-making (Weick 1995) from the information gathered (Resohardijo 2006). Like consolidators, they will use investigation to build societal support, but in their case societal support will confer upon them a greater autonomy, because it sustains the hope that their recommendations may be adopted by a future government, even if the ‘take-up’ by the incumbent government is limited (Wallis 
2013). Thus the catalytic leadership identity may be interepreted as the most radical of all four.

We apply this framework in order to evaluate the effect of the leadership identities expressed by commissioners examining the question of forced municipal mergers in Northern Ireland and NSW.

\section{Northern Ireland}

Prior to 1973, the local government system of Northern Ireland comprised over 70 local authorities of various hues including, inter alia, county boroughs, county councils, urban districts and rural districts, with their common root in the British 1898 Local Government (Ireland) Act. The system had a troubled history following the creation of Northern Ireland in 1920. The civil rights movement, followed in the late 1960s by the three decades of civil strife commonly referred to as 'the Troubles', emerged in part from discontent amongst the Irish-identifying nationalist population with British-identifying unionist dominance of local authorities. Grievances included gerrymandered electoral wards, a restricted franchise, and discriminatory housing and employment practices (Knox 2012, p. 118, Birrell 2009, p.120). As the political situation deteriorated and intercommunal violence spread rapidly in the early 1970s, the British government suspended the parliament at Stormont and introduced a system of direct rule from Westminster.

The introduction of direct rule coincided with reorganisation of the local government system arising from a government-sponsored review (Government of Northern Ireland 1970). Existing local authorities were merged to form one tier of twenty-six new district councils, but virtually all of their functions had been removed and given to statutory boards or departments overseen by Ministers appointed by London. The district councils were funded 
through a combination of grants from central government, domestic and business rates. With a modest range of discretionary functions, minor spending powers, and an increasingly dense regional administrative system, the local authorities limped along until the period after the signing of the Good Friday Agreement in 1998.

The Agreement ushered in a new era of institutional reform to Northern Ireland, including a 108-member elected Assembly at Stormont (operating according to consociational powersharing arrangements) and an Executive comprising 11 (later 12) Departments allocated between Ministers from all the major parties. One of the first acts of the devolved government was to commission a review of the administrative system, though controversially, if understandably given the political sensitivities, excluding the fledgling civil service Department structure. This review was known as the Review of Public Administration (RPA) and was launched in 2002. While the RPA's remit included reorganisation of health and education bodies, as well as a plethora of other quangos, it has become most closely associated with its work on local government re-organization.

The composition of the group selected to undertake the RPA itself proved something of a controversy. The process was primarily conducted civil servants from the new Office of the First Minister and Deputy First Minister (a central executive Department combining the leaders of the largest unionist and nationalist parties respectively), supported by a panel of independent experts, including academics. Knox (2012, p. 120) records criticisms of the decision to put civil servants in charge of the administrative reform process, which, in line with the Clokie and Robinson (1937) typology, primarily reflected a desire to have an impartial commission-like arrangement, but one which could avail of technical input. In this respect, the RPA was empowered to function as an interpretative authority, though it remains to be seen which leadership identity this body sought to express and layer upon this primary identity. 
The RPA published some early public consultation papers that suggested reducing the number of local authorities to seven, eleven or fifteen, and increasing their range of functional responsibilities. In the political background to its work, the Northern Ireland Assembly was suspended and direct rule reintroduced in 2002, but the British Secretary of State opted to keep the RPA active and his office announced the outcome of the consultation process in 2005. Though not a final report, the decision of the Northern Ireland Office was that the twenty-six local authorities would be consolidated to just seven new councils, and given powers transferred from a number of quangos and devolved departments in respect to planning, roads, regeneration and fostering community relations. Following this process, a new and politically independent boundary commissioner was appointed in 2006, with the objective of reporting on the shape of new council boundaries, which were scheduled to come into being in 2009 .

With the reinstatement of the Northern Ireland Assembly, however, a new Minister for the Environment announced a review of the local government aspects of the RPA recommendations, and re-opened the debate concerning the number of councils. Unlike the previous RPA work, this review was undertaken by a committee chaired by the Minister, and its final report published in 2007 suggested rationalisation of the twenty-six authorities to 11 rather than 7 new councils by 2011 .

The proposal for a range of new functions to be devolved to the new councils from regional quangos and departments remained. A consultancy firm was employed to present options for this transfer of functions, and the Northern Ireland Assembly passed legislation repealing the 1971 Act that had established the 26 district councils model. An independent Local Government Commissioner was appointed, and this commissioner presented final recommendations for the eleven new local government districts in Northern Ireland in 2009. 
Political disputes over the proposed new local authority boundaries delayed progress, however, and in 2010 the proposed reforms were abandoned due to a lack of cross community support within the Executive. Elections thus took place in 2011 in the 26 stillexisting district councils, with plans for the new local councils postponed until the next round of elections in 2014. Finally, 13 years after the launch of the RPA, eleven new 'supercouncils’ with extended responsibilities finally came into being in April 2015.

Having complained for many decades of lacking real powers, elected councils were given new functions concerning such issues as local economic development, urban regeneration and tourism. Perhaps most significantly, powers over community planning and development were returned to local authorities, having being removed from them in 1973. An interesting provision in the legislation creating the new councils (the Local Government Act (Northern Ireland) 2014, Section 66) required that they 'must make arrangements to secure continuous improvement' in the following areas:

- $\quad$ Strategic effectiveness

- $\quad$ Service quality

- $\quad$ Service availability

- Fairness

- Sustainability

- Efficiency

- Innovation

While these were important changes to the local government system, and represented part of a wider 'bedding down' of the post-conflict governance arrangements, local councils still 
remain subject to the demands of the devolved departments. Provisions in the councils’ founding legislation obliged local authorities to provide reports and information upon demand by any department, with no provision to refuse such requests.

The troubled evolution of local government consolidation in Northern Ireland through the Review of Public Administration identifies routine involvement along the road to consolidation of a variety of commissions and groups which excluded politicians. Of interest is the manner in which political considerations could still veto or reverse decisions by independent commissions, exemplified by the changes in the number of local councils and their geographic boundaries. And although they have new functional remits, the eleven new 'super-councils' could not divest themselves of traditional unionist-nationalist divisions over such issues as council names and the relative prominence of symbols, including flags and language (Irish and English).

\section{Discussion}

A relatively low risk approach to agenda adjustment, with very little deviation from the intention of appointing office-holders to focus on the issue of amalgamation, runs as a common strand through these developments; namely: (i) the charging of the RPA to review local government; (ii) the review of the RPA recommendations by a committee chaired by the Minister for the Environment; and (iii) the appointment of a consultancy firm to consider the transfer of functions. However, as this process unfolded, the ministerial committee, in particular, widened the scope of stakeholder engagement. To some degree this reflected the politically charged nature of the issue and the impracticality of keeping it within the type of insulated policy community that formed around the RPA. The pattern is therefore an evolutionary shift from a conservator to a consolidator identity for the commissioners involved. However, in the next section we will consider whether a similar shift from 
conservator to consolidator occurred in a different and less politically conflicted jurisdiction in Australia.

\section{NSW}

The largest of the seven Australian state and territory local government systems, NSW local government consists of 152 'general purpose councils', 12 'special purpose councils' as well as the NSW Aboriginal Land Council. The controlling apparatus that governs NSW local councils comprises the NSW Office of Local Government (OLG) (formerly the Division of Local Government (DLG)), the NSW Local Government Grants Commission, and various other supplementary bodies, most notably the Independent Pricing and Regulatory Tribunal (IPART), which regulates not only property tax increases, but also numerous other municipal fees and charges. The legislative foundations of NSW local government rest on the NSW Local Government Act (1993), as subsequently amended. In common with other Australian local government systems, NSW local government exists as a 'creature of statute', since the NSW Government possesses extensive regulatory powers over local government, including the unfettered authority to forcibly merge local authorities.

Australian local government fulfils a relatively limited range of functions, focused largely on ‘services to property’; it does not provide many 'services to people’, such as education, fire protection and police, which are the primary responsibility of state and territory governments in the Australian federal system of government. NSW local authorities provide local infrastructure, including local roads, and local services, such as sewage and solid waste disposal, with some regional, rural and remote councils running local water utilities.

NSW local government is funded through property taxes, fees and charges for services, intergovernmental grants, developer charges and various other sources. A long-standing system of 'rate-pegging' in NSW sets an annual ceiling on property tax increases, which is 
administered by IPART. It has recently been amended to enable 'special variations' in property tax increases above the 'rate-peg' for approved councils. NSW local authorities fall under elected councillors and usually an indirectly elected mayor, who face four-yearly election cycles. The operation of councils is conducted by a professional bureaucracy led by a general manager responsible for the day-to-day running of a local authority.

In August 2011, the NSW Minister for Local Government in a newly elected conservative Liberal/National Coalition Government convened a Destination 2036 workshop in the regional city of Dubbo with mayors and general managers gathered from all NSW local authorities. At this workshop, the Minister for Local Government stressed the severe financial challenges confronting NSW local government and urged local authorities to cooperate with the NSW Government in a reform program to meet these challenges. While several consequences flowed from Destination 2036, its major import lay in the establishment of a three-person Independent Local Government Review Panel to investigate options for reform and to make recommendations to the NSW Government. The Panel comprised two former council general managers and a former administrative head of the Australian Local Government Association.

In November 2012, the Panel (2012, p.3) released a ‘discussion paper’ entitled Better, Stronger Local Government: The Case for Sustainable Change in which it set out the views of the Panel on the problems confronting NSW local government and various putative solutions to these problems. Better, Stronger Local Government emphasised the adverse financial circumstances confronting local authorities and proposed, inter alia, a comprehensive program of structural reform centred in metropolitan NSW as a means of addressing financial sustainability. Public feedback was sought on the views expressed in Better, Stronger Local Government. 
In April 2013, the Panel published Future Directions for NSW Local Government: Twenty Essential Steps as its interim report (ILGRP 2013a). Future Directions considered twenty aspects of NSW local government and made various recommendations in terms of these elements, including radical compulsory consolidation of numerous Sydney metropolitan councils and the creation of county councils from the dissolution of existing small country councils, largely on grounds that there existed too little revenue and insufficient skilled staff to maintain the current 152 councils in NSW. Future Directions (2013a, p. 6) argued that 'it is also clear that the financial base of the sector is in urgent need of repair' since 'many councils face very serious problems that threaten their sustainability and provision of adequate services to local communities', adding that 'put simply, there are too many councils chasing too few resources'.

The Panel then travelled throughout NSW engaging in public consultation on Future Directions with local councils and other interested parties. While public support existed for many of the non-controversial measures proposed in Future Directions, the forced merger program advocated in Future Directions was greeted with dismay by the NSW local government sector. It was attacked on several counts, not only because of the absence of any empirical basis for its merger recommendations, but also because of the poor quality of much of its commissioned research, particularly Assessing Processes and Outcomes of the 2004 Local Government Boundary Changes in NSW by Jeff Tate Consulting (2013). In addition, the Minister for Local Government publically stressed on several occasions that the NSW Government had a longstanding policy against forcing mergers in local government.

After its extensive public consultation process and further deliberations, the Panel compiled a final report in October 2013. Entitled Revitalizing Local Government, the Final Report and its three supporting documents (Volume 1 Consultation Report, Volume 2 Research Report and Volume 3 Strengthening Far West Communities) did little to undo the reputational 
damage to the Panel caused by its Future Directions recommendation of a program of forced mergers.

The major difference between the recommendations of Future Directions compared to the ‘options’ proposed in Revitalizing Local Government lay in a distinct ‘softening' of the call for compulsory council consolidation of Sydney metropolitan councils. While Revitalizing Local Government (2013b, p. 75) still proposed a radical program of mergers for Sydney local government, it dropped its insistence on compulsion and instead recommended 'reconstituting' the existing NSW Boundaries Commission and enabling it to 'independently' assess the proposed amalgamation program on a council-by-council basis before making binding recommendations.

Notwithstanding this revision, Revitalizing Local Government (2013b, p. 7) continued to stress the inevitability of municipal mergers in NSW local government, observing that 'sooner or later amalgamations will have to be part of the package' since 'the number of councils in NSW has halved during the past century and that trend will surely continue'. Moreover, the Panel (2013b, p. 720) reiterated its earlier claim that NSW lacked the resources to support so many local authorities:

Amalgamations and boundary changes are not the panacea for local government's problems, nor are they the only type of structural reform that should be pursued. However, the Panel believes that they are an essential element of a wider package of reforms. Creating a sustainable system that can cope with the challenges of a changing world must involve some reduction in the number of local government areas. NSW simply cannot sustain 152 councils: many are highly dependent on grant support; fiscal imperatives demand efficiencies in government across the board; and there are shortages of highly skilled personnel. The shortage of engineers, for example, is a significant factor limiting the capacity of councils to deal with infrastructure backlogs'.

The NSW Cabinet delayed until early January 2014 before making public Revitalising Local Government. In April 2014, after the sudden resignation of the (then) Premier O’Farrell, the incoming new Premier Baird reshuffled the NSW Cabinet, replacing Don Page with Paul 
Toole as Minister for Local Government . These momentous circumstances may account for the fact that the NSW Government only formally responded to the recommendations in Revitalising Local Government in September 2014 in the form of a Fit for the Future policy package.

Under Fit for the Future, each local authority must undergo a self-assessment exercise to determine if it (a) is 'sustainable', (b) is 'efficient', (c) 'effectively manages infrastructure and delivers services for communities' and (d) 'has the scale and capacity to engage effectively across community, industry and government' (OLG, 2014). Assessment reports were to be lodged with the NSW Government by 30 June 2015. To assist in this process, the NSW Government appointed ‘expert facilitators’ to help local authorities to explore regional collaboration with other councils under newly established Joint Organisations (JOs), to be established following four 'pilot' JOs trialled in early 2015. In essence, JOs represent regional associations of local councils established to foster and expand shared service delivery and other forms of council collaboration.

While the Fit for the Future framework originally planned for an Expert Panel to evaluate assessment reports submitted by local authorities to determine if councils meet Fit for the Future criteria, the panel was subsequently replaced by the NSW Independent Pricing and Regulatory Tribunal (IPART). The NSW Government planned torovide \$258 million to groups of councils that decide to voluntarily merge. Councils that were deemed to have satisfied Fit for the Future guidelines would enjoy several benefits, including 'a streamlined IPART process for rate increases above the rate pegging limit' and interest subsidies on loans for capital expenditure (OLG, 2014, p. 15). Councils that are judged not to meet Fit for the Future criteria wouldface forced mergers. 
The NSW Government held a general election in March 2015 and the proposed reforms under its Fit for the Future program, including the possibility of forced mergers, encouraged the local government sector to seek clarity from Minister for Local Government Toole on his commitment not to force mergers. These efforts met with evasion and prevarication, further fuelling speculation that the re-elected NSW Government would implement the radical amalgamation program proposed by the Panel in Future Directions and Revitalizing Local Government.

In the wake of the election, the NSW Government departed substantially from its earlier Fit for the Future program. Without warning, on 27 April 2015, the Minister for Local Government announced that IPART would replace the Expert Panel in the assessment of council submissions. Moreover, IPART employed different assessment criteria than the ones that had been delineated in Fit for the Future. On 5 June 2015 - a mere 25 days from the 30 June 2015 deadline for council submissions under the Fit for the Future - IPART (2015a) released its final Methodology for the Assessment of Council Fit for the Future Proposals. The IPART (2015a) assessment methodology established ‘adequate scale and capacity’ as its principal criterion, a concept that was given no further elucidation. Drew and Dollery (2015) have argued that the IPART criteria contain serious flaws.

On 20 October 2015, IPART (2015b) published its Assessment of Council Fit for the Future Proposals, which contained its decisions on individual local authorities. IPART (2015b) considered 139 local council proposals from a total of 144 councils, comprising four 'merger' proposals (involving nine councils), 115 'council improvement' proposals and twenty 'rural council' proposals. 52 (37\%) proposals were assessed as 'fit for the future' and 87 (63\%) were determined not to be 'fit for the future'. Of those deemed not fit for the future, 60 met the financial criteria, but did not have adequate 'scale and capacity', 18 had sufficient 'scale and capacity' but were not financially 'fit', and nine had both inadequate 'scale and capacity' 
and failed on financial criteria. All four 'merger' proposals were assessed as 'fit for the future’ (IPART, 2015b).

On $18^{\text {th }}$ December 2015, the NSW Government announced its decision on municipal mergers and proposed that 35 local authorities be established through forced mergers. Little correspondence exists among the recommendations of the Independent Panel amalgamation recommendations, IPART (2015b) merger determinations, and the 35 mergers announced by the NSW Government, suggesting political considerations at play. Under the Local Government Act (1993), in early 2016, the 35 proposals were considered by appointed Delegates - through a public consultation process - and referred to the NSW Boundaries Commission for recommendation to the Minister, who is not obliged to accept these recommendations and thus has the final decision. In the event, almost all 35 merger proposals were sanctioned by Delegates, endorsed by the Boundaries Commission, accepted by the Minister and proclaimed by the Governor of NSW. As at July 2016, a number of these mergers are subject to legal challenge in the High Court and it remains to be seen how many forced amalgamations will ultimately eventuate.

\section{Discussion}

The question of the scope of agenda adjustment and consequent expression of leadership identity in the successive NSW commission reports depends on whether forced amalgamation was always part of the implicit agenda of the appointing authorities in which case the commissioners were simply testing the receptivity of the policy community to this 'pet' reform proposal. Dollery, Grant and Kortt (2013) certainly take this view. They argue that Australian regional governments have displayed a persistent tendency to look first to compulsory consolidation of councils when faced with problems in local government systems, despite the equivocal record of such amalgamations. The Local Government Review 
Panel charged with proposing reforms for the NSW local government system appears to have been deployed with the intention of deflecting or absorbing criticism of compulsory consolidation of councils, and the Panel appears to have acquiesced to this intention. It was quick to release its initial Discussion Paper, which focused the discussion on structural reform as the mechanism for reforming NSW local government, and soon followed it with its interim report, stating that the type of structural reform that was needed was significant consolidation of local councils. At this point, the commission had mainly acted in the role of conservator, limiting public consultation and acting to reconcile opponents to the inevitability of compulsory consolidation of councils.

The Panel then set about engaging in widespread public consultation, indicating broad stakeholder engagement and a switch to a consolidator mode of leadership. In the face of significant criticism of compulsory consolidation of councils, the Panel's final report adopted a less militant tone towards forced amalgamations, and suggested 'reconstituting' the NSW boundaries commission and empowering it to make binding recommendations. If this had been an innovative solution that had emerged from its widespread consultation, one could consider the Panel to have eventually adopted a catalytic identity. However, handing the issue over to a proposed strengthened Boundary Commission would have been just a further 'venue alteration mechanism' to diffuse opposition to the council mergers by offering constantly changing targets. With its insistence that amalgamations must be part of the solution, the Panel in the end must be viewed as having expressed a consolidator leadership identity, attempting to engage with stakeholders in order to build support for the incumbent government's preferred solution. The NSW Government's eventual response to the Panel's recommendation of municipal mergers was a mechanism that offered monetary incentives designed to encourage councils to merge voluntarily, backed by the threat of forced amalgamations of councils that fail to reach newly imposed benchmarks. We will now draw 
the last two sections together by pointing out the similarities between commission leadership in Northern Ireland and New South Wales.

\section{Conclusion}

In the case of the reform of local government in Northern Ireland, it appears that in the initial appointment of the RPA, the government hoped to limit the degree of 'outsider' stakeholder engagement, possibly to limit its exposure to the state's nationalist-unionist divisions, and allow the commission to focus on its remit of reforming the system of local government. That it failed to sustain this conservator approach to keep the issue within an insulated policy community could be attributed to the politically charged nature of what is, in the Northern Ireland context, a hugely salient feature of the constitutional arrangement. However, amalgamations are unlikely to have the same salience in Australia, where they intermittently rise to prominence as part of a familiar theme in local government reform.

It is interesting to note, however, that a similar shift from a conservator to a consolidator leadership identity can be observed in Australia as in Northern Ireland. From this we conclude that the scope for the other identities, such as advocate and catalyst, is only likely to emerge when a local government commission is given a broader remit with a greater attendant authority to consider local government reform in all its aspects. The most notable example of this is the Lyons Inquiry in the UK (2007), which generated from widespread stakeholder engagement a catalytic vison of a 'place shaping' community leadership role for local government that continues to shape policy discussion in this area in the UK more than eight years after the appointing government largely rejected its recommendations. 
Table 1: Typology of Commissioner Identities

\section{Low Risk Persuasive High Risk Persuasive}

\begin{tabular}{lcc}
\hline Low Risk Investigative & 'Conservator' & 'Advocate’ \\
High Risk Investigative & 'Consolidator' & 'Catalyst'
\end{tabular}

Table 2: Reform contexts

\begin{tabular}{|c|c|c|c|}
\hline & & New South Wales & Northern Ireland \\
\hline & Population (m) & & 1.8 \\
\hline & $\begin{array}{l}\text { Number of pre- } \\
\text { existing local } \\
\text { authorities }\end{array}$ & & 26 \\
\hline \multirow{2}{*}{$\begin{array}{l}\text { Number of local } \\
\text { authorities } \\
\text { recommended }\end{array}$} & $\begin{array}{l}\text { 'Conservator' } \\
\text { Commission }\end{array}$ & & 7 \\
\hline & $\begin{array}{l}\text { 'Consolidator' } \\
\text { Commission }\end{array}$ & & 11 \\
\hline $\begin{array}{l}\text { Recommendations } \\
\text { accepted or amended } \\
\text { by political authority }\end{array}$ & & & $\begin{array}{l}\text { Yes (following boundary } \\
\text { amendments) }\end{array}$ \\
\hline $\begin{array}{l}\text { Source of Commission } \\
\text { establishment }\end{array}$ & & & Part of \\
\hline No of members & & & \\
\hline
\end{tabular}




\section{REFERENCES}

Andrews, R. W. and Brewer, G. A. (2013), 'Social capital, management capacity and public service performance: Evidence from the US States', Public Management Review, 15 (1), pp. $19-42$.

Ashforth A (1990) Reckoning schemes of legitimation: On commissions of inquiry as power/knowledge forms. Journal of Historical Sociology 3(1): 1-22.

Birrell, D. (2009) Direct Rule and the Governance of Northern Ireland (Manchester: Manchester University Press)

Brown AD (2000) Making sense of inquiry sensemaking. Journal of Management Studies 37(1): 45-75.

Brunsson, Nils and Olsen, Johan P. The Reforming Organization (Bergen: Fagbokforlaget, 1993).

Chapman RA (ed.) (1973) The Role of Commissions in Policy-Making. Australia: Allen \& Unwin.

Clokie, H. M. and Robinson, J. W. (1937), Royal Commission of Inquiry: The Significance of Investigations in British Politics, Stanford: Stanford University Press.Denters, B. and Rose, L. E. (eds.) (2005), Comparing Local Governance: Trends and Developments, Basingstoke, Palgrave Macmillan.

Cohen MD, March JG and Olsen JP (1972) A garbage can model of organizational choice. Administrative Science Quarterly 17(1): 1-25.

Denters, B., \& Rose, L. E. (2004), 'Towards local governance. Comparing local governance. Trends and developments', London, Palgrave Macmillan.

D’Ombrain N (1997) Public inquiries in Canada. Canadian Public Administration 40(1): 86107.

Dollery, B. E. Garcea, J. and LeSage, E. (eds.) (2008), Local Government Reform: A Comparative Analysis of Advanced Anglo-American Countries, Cheltenham, Edward Elgar.

Dollery, B. E., Grant, B. and Kortt, M. (2012), Councils in Cooperation, Sydney, Federation Press.

Dollery, B. E., Kortt, M. and Grant, B. (2013), Funding the Future, Sydney, Federation Press. 
Dollery, B. E and Robotti, L. (eds) (2008), Theory and Practice of Local Government Reform, Cheltenham, Edward Elgar.

Drew, J. and Dollery, B. (2015), 'Less Haste More Speed: The Fit for the Future Reform Program in New South Wales Local Government', Australian Journal of Public Administration, DOI: 10.1111/1467-8500.12158.

Faulk, D. and Hicks, M. (2011), Local Government Consolidation in the United States, Amherst, Cambria Press.

Game, C. (2006), 'Comprehensive performance assessment in English local government', International Journal of Productivity and Performance Management, 55(6), 466 - 479.

Garcea, J. and LeSage, E. (2005), Municipal Reforms in Canada, Toronto, Oxford University Press.

Gilligan G (2002) Royal commissions of inquiry. Australian \& New Zealand Journal of Criminology 35(3): 289-307.

Government of Northern Ireland (1970) Review body on Local Government in Northern Ireland, Cmd 546. Belfast, Her Majesty’s Stationery Office.

Haggard S and Kaufman RR (1992) The Politics of Economic Adjustment: International Constraints, Distributive Conflicts, and the State. Princeton, NJ: Princeton University Press.

Hall PA (1993) Policy paradigms, social learning, and the state: The case of economic policymaking in Britain. Comparative Politics 25(3): 275-296.

Heifetz RA and Linsky M (2002) Leadership on the Line. Boston, MA: Harvard Business School Press.

Hood, C. and Lodge, M. (2006), Politics of Public Service Bargains, Oxford, Oxford University Press.

Howard J (1987) The National Inquiry into Local Government Finance. Paper prepared for the Public Policy Programme. Canberra: Australian National University.

Independent Local Government Review Panel. 2012. Better, Stronger, Local Government: The Case for Sustainable Change. Sydney: Independent Local Government Review.

Independent Local Government Review Panel. 2013a. Future Directions for NSW Local Government: Twenty Essential Steps. Sydney: Independent Local Government Review.

Independent Local Government Review Panel. 2013b. Revitalizing Local Government. Sydney: Independent Local Government Review.

Independent Pricing and Regulatory Tribunal (IPART) (2015a), Methodology for Assessment of Council Fit for the Future Proposals, IPART, Sydney. 
Independent Pricing and Regulatory Tribunal (IPART) (2015b), Assessment of Council Fit for the Future Proposals, IPART, Sydney.

Jeff Tate Consulting (2013), Assessing Processes and Outcomes of the 2004 Local Government Boundary Changes in NSW. Adelaide: Jeff Tate Consulting.

Johansson, E. (2003), 'Intergovernmental Grants as a Tactical Instrument: Empirical Evidence from Swedish Municipalities’, Journal of Public Economics, 87, 883-915.

Korac-Kakabadse, A., \& Korac-Kakabadse, N. (1997), 'Best practice in the Australian Public Service (APS): An examination of discretionary leadership’, Journal of Managerial Psychology, 12(7), pp. 433-491.

Kingdon J (1995) Agendas, Alternatives, and Public Policies. London, UK: Longman Publishing Group.

Knox, C. (2012) The reform of public administration in Northern Ireland: A squandered opportunity? Administration, Vol. 60 (1), pp.117-38.

Lago-Penas, S. and Martinez-Vazquez, J. (eds.) (2013), Challenge of Local Government Size, Cheltenham, Edward Elgar Press.

Mackintosh J (1970) The Royal Commission on Local Government in Scotland, 1966-69. Public Administration 48(1): 49-56.

McGredy Winder \& Co (2013a), Future Prosperity of the Hawkes Bay Region, McGredy Winder \& Co, Auckland.

McGredy Winder \& Co (2013b), Potential Costs and Savings of Local Government Reform in Hawkes Bay, McGredy Winder \& Co, Auckland.

New England Education and Research (NELG) (2013), Bigger is Not Always Better, NELG, Armidale.

Office of Local Government (OLG)(2014). Becoming Fit For The Future. Available at http://www.fitforthefuture.nsw.gov.au/for-councils.

Prasser S (1985) Public inquiries in Australia: An overview. Australian Journal of Public Administration 44(1): 1-15.

Prasser S (1994) Royal commissions and public inquiries: Scope and uses. In Weller P (ed.) Royal Commissions and the Making of Public Policy. Melbourne, Vic: Macmillan Education.

Prasser S (2006) Royal Commissions and Public Inquiries in Australia. Chatswood, NSW: LexisNexis Butterworths.

Resodihardjo SL (2006) Wielding a double-edged sword: The use of inquiries at times of crisis. Journal of Contingencies and Crisis Management 14(4): 199-206.

Rowe, M. and McAllister, L. (2006), 'The Roles of Commissions of Inquiry in the Policy Process', Public Policy and Administration, 21, 99-115. 
Sabatier P (1988) An advocacy coalition framework of policy change and the role of policyoriented learning therein. Policy Sciences 21(2-3): 129-168.

Sancton, A. (2011). Canadian Local Government: An Urban Perspective, Toronto, Oxford University Press.

Shah, A. (ed.) (2006), Local Governance in Industrial Countries, Washington, World Bank.

Sheriff PE (1983) State theory, social science, and governmental commissions. American Behavioral Scientist 26(5): 669-680.

Sulitzeanu-Kenan R (2006) Blame Avoidance and the Politics of Public Inquiries in the UK, 1984-2003. Oxford: University of Oxford.

Tomkinson, R. (2007), Shared Services in Local Government, Aldershot, Gower Publishing.

Wallis J (2013) The logic of fateful choices faced by the leaders of commissions of inquiry. American University of Sharjah, School of Business and Administration working paper series, 2013-12-09.

Weick, K.E. (1995). Sensemaking in Organizations. Thousand Oaks, CA: Sage.

Weller P (ed.) (1994) Royal Commissions and Public Enquiries in Australia. Macmillan Education.

Zegart AB (2004) Blue ribbons, black boxes: Toward a better understanding of presidential commissions. Presidential Studies Quarterly 34(2): 366-393. 